\title{
Фольклористика
}

УДК 8 (471.67)

\section{М.М. Курбанов}

\section{ИСТОРИЧЕСКОЕ ВЛИЯНИЕ ТВОРЧЕСКИХ ТРАДИЦИЙ ПЕРСИДСКОЙ КУЛЬТУРЫ НА РАЗВИТИЕ ФОЛЬКЛОРА НАРОДОВ ЮЖНОГО ДАГЕСТАНА}

В статье освещаются проблемы мощного влияния Средневековой персидской культуры на формирование и развитие фольклора народов Южного Дагестана. В Дербентском регионе, Табасаране и Лезгистане V-XVIII вв. создался региональный этнический, языковой и культурный симбиоз, который привел фольклор табасаранов, лезгин, азербайджанцев, переселенных сюда ираноязычных татов, персов, арабов к взаимообогащению и интенсивному развитию. Бытовые, культурные и торговые связи способствовали тому, что большинство жителей свободно начали владеть «старым тюркским», персидским, лезгинским и табасаранским языками, которые использовали этносы в общении, торговле и в быту. Результатом влияния персидской народной и ашугской поэзии на развитие творчества народов региона можно считать формирование единой системы жанровых разновидностей внеобрядовой лирики и свадебной поэзии, что отразилось в фольклоре табасаранов, лезгин, агульцев в виде бендов-четверостиший. Позитивному влиянию подверглись и сказки народов данного региона. Они обогатились восточными сюжетами, темами, идеями, колоритными образами, персидской топонимикой, что составило неповторимую поэтику жанра.

Ключевые слова: Средневековье, влияние, контакты, Южный Дагестан, ассимиляция, бенд, заимствование, этносы, жанры.

DOI: $10.35634 / 2412-9534-2021-31-2-392-397$

В последние годы в российской фольклористике внимание исследователей привлекают исторические процессы взаимовлияния культур и традиций, которые рассматриваются как естественный результат торговых, культурных, военных и бытовых контактов народов мира. Однако ученые недостаточно изучили одностороннее влияние мощных и богатых культур на развитие фольклора малых народов и этнических групп. В фольклоре достаточно много примеров того, как богатейшие культуры под своим мощным влиянием исторически трансформировали отдельные стороны устного творчества того или иного народа, даже изменяли формы некоторых этнических фольклорных жанров.

В культурологии и фольклористике известны случаи благотворного развития жанров и жанровых разновидностей устного народного творчества тех или иных стран, испытавших воздействие шести древних цивилизаций: древнекитайской, древнеиндийской, древнеперсидской, древнеегипетской, древнегреческой и древнеримской. Аналогичное позитивное многовековое влияние оказала древняя персидская культура на всестороннее обогащение фольклора народов Южного Дагестана и Закавказья в силу исторических, географических, культурных, торговых, военных и бытовых контактов этих кавказских и персидских народов и этнических групп.

В Средневековье Дербент как военный форпост, расположенный на границе Хазарского каганата и Сасанидского Ирана, сыграл исключительную роль в жизни народов Южного Дагестана, особенно в период, когда эти земли были захвачены шахиншахом Иездигардом II (V в.). А при правлении Персией Квабад-шахом, затем его наследником Хосровым I Ануширваном (V-VI вв.) Сасаниды начали укреплять свои северные границы, пролегающие рядом с воинствующими племенами Хазарского каганата, построив за десятки лет Дербентскую цитадель «Нарын-калу» и «Горную стену» («Дагбары»), растянувшуюся по Джалганскому хребту вглубь Табасарана на 40 км. Кроме того, для обороны пограничных сооружений шах Ануширван поселил по обе стороны «Дагбары» десятки тысяч персидских семей из Рушана, Гиляна [7, с. 207] и других мест Северного Ирана и основал селения Камахи, Гюмейди, Митаги, Зиль, Дарваг, Марага, Хилипенджи, Бильгади, Зидьян и др., жители которых сначала говорили на родном фарси, а со временем - на разговорном диалекте старого тюркского языка.

В эти же века на территории проживания местных аборигенов в результате иранских (V-VI вв.), арабских (VIII вв.) и тюрко-сельджукских захватнических войн (XI-XII в.) были потеснены местные жители, и на их плодородных землях осели переселенные в Дагестан ираноязычные таты, персы, арабы 
и турки. Со временем в течение нескольких веков на относительно небольшой территории Южного Дагестана прошла интенсивная ассимиляция народов, этносов и культур, но общим для всех жителей региона языком межнационального общения и торговли в конечном итоге остался диалект древнего тюркского языка. Как отмечает исследовательница фольклора дагестанских азербайджанцев М.Ш. Шихиева, «процессы формирования азербайджанского народа с его этническими группами, особенно в зоне древнего города Чора (Дербента), были весьма сложными и неоднородными. Этот конгломерат племен и народов на относительно небольшой территории создал уникальное устное народное творчество, вобравшее в себя эпические и лирические жанры разных этносов с многообразием тем, сюжетов, идей, образов, традиций как самобытных, так и международного плана» [8, с. 4-5].

Таким образом в Средневековье в Южном Дагестане, в частности в Дербентской зоне и Табасаране, создался региональный этнический, культурный и языковой симбиоз, который привел фольклор народов Южного Дагестана (табасаранов, лезгин, азербайджанцев, переселенных сюда ираноязычных татов, персов, арабов и др.) к взаимообогащению и интенсивному развитию. Бытовые, экономические и торговые связи привели к тому, что большинство жителей Дербента, прилагающих к нему земель и Табасарана свободно начало владеть «старым тюркским», персидским, лезгинским и табасаранским языками, которые использовали этносы в общении, торговле и в быту. Эти вековые торговые, экономические, культурные, военные и бытовые взаимосвязи народов Южного Дагестана не могли не влиять на благоприятное развитие народного творчества всего региона. В этом аспекте ведущую роль в обогащении культур горцев сыграла древняя персидская цивилизация и фольклор с богатыми традициями эпического и лирического творчества.

Другой особенностью фольклора горцев Южного Дагестана следует считать то обстоятельство, что он в Средневековье развивался на просторах и в городах Великого шелкового пути (со II в. до н. э., до XVI в. н. э.), проходившего из Персии через Дербент, крупного торгового и культурного центра Кавказа, куда со своими товарами приезжали купцы со всего Закавказья и жители Страны гор. Эти и другие естественные причины, по которым сформировалось межнациональное взаимодействие, способствовали взаимообогащению и эволюционному развитию народного творчества этносов Юждага в течение многих столетий нелегкой и тревожной истории.

Влияние персидских эпических и лирических традиций на народное творчество этносов Южного Дагестана в Средневековье прослеживается, прежде всего, в песенном творчестве. Результатом интенсивного влияния персидской народной и ашугской поэзии на развитие поэзии народов исследуемого региона можно считать формирование единой системы жанровых разновидностей внеобрядовой лирики и свадебной поэзии - бендов-четверостиший. Они существуют в фольклоре табасаранов, лезгин, агульцев. «Бенд» - четверостишие персидского происхождения, состоящее из двух бейтов (двустиший в поэзии народов Востока, которые веками создавали рубаи, газели, касыды и другие жанры восточной лирики) и имеющее $7,8,10,11,14$ слогов с рифмами «аааб», «абаб», «абба», «аабб», «абсб». Слово «бенд», кроме того, в семантическом смысле означает - «влюбленный», а также «строфа», «куплет» $[2$, с. 90$]$.

Если лирические и свадебные песни народов Центрального Дагестана (аварцев, даргинцев, лакцев, кумыков и др.) представлены в различных строфических формах и объемах (2-3-4-5-6-10 и более строках), то упомянутые жанры и их разновидности (песни о любви, песни-проклятия, семейно-бытовые, об отходниках, социальные, гражданские, свадебные и др.) за редким исключением бытуют в форме бенда у табасаранов, лезгин, агульцев и др,. Для иллюстрации необходимо привести примеры из свадебной и любовной лирики народов Южного Дагестана.

1. Табасаранский свадебный бенд:

Ярхла рякъди дуфнача, (7) Пришли длинной дорогой мы,

Гьюрмат ап Іан, я къавум. (7) Почитай нас, дорогой сват.

Айвандикк дийигънача, (7) Стоим под балконом мы,

Хулаз гъач йип, жан къавум. (7) Пригламай домой, жан сват.

2. Агульский свадебный бенд:

Арсуран сиви велди, (7) От тяжести твоего серебра,

Сувар рахай гъузуна. (7) Даже горы эхом отдают.

Чи сусан битlар велди (7) От красоты нашей невесть

Дюнья ирчай гъузуна. (7) Даже мир прекрасней стал. 
3. Лезгинский свадебный бенд:

Каманавай лацьы манат (8) Пуговицы из серебряной монеты -

Жи ичийи свас чвез аманат.(8) Наша невеста вам на хранение.

Альккна вач харай либас (8) Надевай красивые наряды -

Ваз угъур хьуй, чан ицІийи свас.(8) Счастливого пути тебе, невеста.

Аналогично оформляются большинство внеобрядовых (в частности, любовных) песен упомянутых народов Южного Дагестана. В них навсегда закрепилась форма бенда с соответствующими рифмами, цезурами и размерами стихосложения.

1.Табасаранская песня о любви:

Т1убахъ хъайи арсран т1ублан (8) Кольио, что на пальще,

Я бай, уву тувуб дариз. (8) Эй, юнома, не ты мне дарил.

Ккунду дупну, дидкан гьап1за,(8) Тебя люблю, а что мне делать,

Я бай, уву рякъюрдариз? (8) [6, с. 33] Если я не встречаю тебя?

2. Лезгинская песня-страдание:

Гьуьлерилай аних галай, (8) За морями мой любимый,

Ярдин дидар акваз кlан я.(8) Очень хочу увидеть его.

Чандилайни кlан хьайи яр, (8) Полюбила больше жизни -

Ахварай къван акваз кlан я. (8) [3, с. 73] Хоть бы увидеть его во сне.

3. Агульская песня о «горящем сердце»:

Агь фаиу, фаиу фикир,(7) Горе, горе развеять,

Фатада сувар кканде.(7) Высокие горы нужны.

Ц1 аяр керхьу угу юрк1, (7) Горящее сердие чтобы

Кедатас гьюлар кканде! (7) [1, с.18] Потушить, моря нужны!

В популяризации международных эпических сюжетов, сохранившихся до сих пор у народов Кавказа и Востока, особую роль в старину играли любители народных сокровищ, купцы, ашуги, странствующие богомольцы (дервиши), нагъылчылар ${ }^{1}$, кисаханы ${ }^{2}$. Последние, имея необычную память и храня в ней сюжеты и мотивы, собирали вокруг себя на базарах, в караван-сараях, чайханах соответствующую публику, тем самым распространяя как произведения родного фольклора, так и иноязычные тексты. Талантливые сказители и ашуги умели приспосабливаться к вкусам, настроениям и запросам любой публики. Кроме того, сказочники и кисаханы становились соавторами текстов, поскольку в случае запамятования деталей текстов мастерски могли использовать хранящиеся в их уникальной памяти «общие места», вводные эпизоды, нравоучительные притчи, пословицы и поговорки. Поэтому любое произведение у талантливого ашуга или кисахана при повторном исполнении могло звучать по-новому.

Помимо этого, в последние века в Дербенте сложилась традиция проведения ежегодных и ежеквартальных состязаний маститых ашугов и молодых певцов, в которых участвовали иранские, азербайджанские, лезгинские, табасаранские и татские мастера, исполняя свои импровизации, популярные восточные дастаны, предания, притчи и легенды. Как отмечают исследователи, ашугство как эстетическое явление, возникло в XII-XV вв. в Персии, Азербайджане и Армении. Согласно традиции, проигравшие в состязаниях ашуги под аплодисменты и овации публики, дарили свои четырехструнные чунгуры победителям в знак восхищения их талантом. А имена победителей быстро становились популярными во всех городах Дагестана и Закавказья.

Среди эпических жанров народов Южного Дагестана, подвергшихся большему влиянию богатейшего фольклора иранских народов, необходимо выделить волшебно-фантастические сказки. Интенсивные межплеменные торговые и бытовые контакты народов Дербентской зоны, начиная с V в., ассимиляционные процессы в регионе, где господствовали персы до прихода арабов и исламизации этносов, привели к тому, что более 20 \% лексики языков народов Южного Дагестана представляют

\footnotetext{
${ }^{1}$ Нагъылчылар (азерб. яз.) - сказитель, сказочник, рассказчик.

${ }^{2}$ Кисахан (табас. яз.) - (досл. «хан рассказа») - профессиональный сказитель, хранящий в памяти большой арсенал фольклорных эпических сюжетов.
} 
персизмы и арабизмы. Персы и арабы, контактируя с местным населением, естественно, знакомили его с произведениями своих народов. И это благоприятно сказалось на обогащении местной культуры лирическими традициями и эпическими сюжетами, почерпнутыми из фольклора этносов Ирана.

С помощью местных ашугов или любителей народной поэтической словесности в устное творчество народов Юждага проникли популярные мотивы и целые сюжеты, повествующие о персонажах персидско-таджикского эпоса «Шах-наме» (Рустам Зал, Сохраб и др.), азербайджанских эпосов («Сказание о Деде Коркуте», «Кер-оглы»), любовно-романтических дастанов народов Востока («Лейли и Меджнун», «Хосров и Ширин», «Ашыг Гариб», «Шах Исмаил», «Тахир и Зухра» и др.), а также циклы целостных сюжетов сказок или их варианты о богатырях («пяхливанах») и т. д.

Историк и знаток персидской культуры А.Е. Крымский отмечал, что «на караванных путях от Малой до Средней Азии и на морских путях из Средиземного моря в Индию на протяжении веков существовал определенный фонд занимательных сказок, рассказов и повестей. Различные народы, жившие в этом регионе, оформляли эти сюжеты, основываясь на присущих всем им общих представлениях, и привносили лишь детали, связанные с местными реалиями» $[4$, с.18]. Таким же образом многие эпические сюжеты в течение Средневековья оказались в арсенале табасаранских сказочников, обогатив этнический фольклор древними персидскими, арабскими и азербайджанскими текстами и традициями поэтики этих жанров.

Из пехлевийской (центрально-персидской) сказочной традиции, что считается доминирующей в персидской культуре, табасаранский, агульский, лезгинский этносы заимствовали сюжеты серии «Хазер офсане» («Тысяча сказок», «Тысяча и одна ночь», «Сказки Шахерезады»), сказок о шахах, падишахах, а также циклы богатырских сюжетов о Рустаме Зале и его сыне Сухрабе, которые являются эпическими персонажами персидского-таджикского эпоса «Шах-наме», популярными на всем Ближнем и Среднем Востоке и др. Но в табасаранском фольклоре эти сюжеты трансформировались, насыщаясь деталями горского колорита. Это сказки «Рустам Зална шах» («Рустам Зал и шах»), «Рустам Зал ва Сухраб» («Рустам Зал и Сухраб») и др. В последнем использован «бродячий сюжет» о «поединке отца с сыном», популярный в сказках и эпосах многих народов мира.

Как говорится в персидском варианте «бродячего сюжета», эпический герой Рустам, отправляясь на долгое время в поход против местных и иноземных врагов Персии, предупредил жену, чтобы при рождении сына надеть на его ручку специальный браслет с красивым камнем. Через двадцать лет во время единоборства с молодым противником отец убивает Сухраба, и тогда по браслету богатырь узнает родного сына. Сюжеты о «непобедимом» Рустам Зале как о драконоборце и защитнике персидских народов от произвола захватчиков и жестоких правителей отражены в татских волшебных сказках под названиями «Рустам Зал» и «Бижон и Менежон», в азербайджанских, табасаранских и лезгинских волшебно-фантастических сюжетах.

Плодотворные контакты народов, вследствие чего фольклор этносов Южного Дагестана обогатился целыми циклами богатырских сюжетов, необходимо рассматривать как естественный результат исторически сформировавшихся межнациональных взаимосвязей. Поэтому богатыри, похожие друг на друга, в творчестве народов Ближнего Востока, Кавказа и Средней Азии - это традиционные персонажи волшебно-фантастических сказок, которые обладают общими признаками, отвечающими запросам и мечтам народов. Они защищают бедных и обездоленных, освобождают красавиц и несчастных из плена мифологических чудовищ, обладают фантастической силой, в честных поединках одерживают победу над аждахой и дэвом и т. д.

Мотивы заимствованных (или же возникших по типологическим законам самозарождения) сюжетов волшебных сказок народов Южного Дагестана схожи между собой: это приключения сына бедняка или сына шаха («шах-заде»), связанные с поисками сказочной красавицы или выполнением поручения отца или матери.. Завязками аналогичных сюжетов служат, как правило, сон одного из родителей, завещание отца, рассказы кисаханов и дервишей о сказочной красоте дочери персидского шаха, о выпитом бедняком заморском волшебном шарабе ${ }^{3}$, вследствие чего юноша влюбился в «воображаемую красавицу», «портрет красавицы, нарисованный неизвестным художником», весть о «луноподобной» дочери иранского шахиншаха, которую хотят выдать замуж за «достойного храбреца» и т. д.

В подобных волшебно-фантастических сказках необычные события могут переплетаться с реальными сценами, возникавшими на шумных базарах, где выступали глашатаи, на узких улицах городов,

\footnotetext{
${ }^{3}$ Шараб (перс. яз.) - сладкий напиток, якобы обладающий волшебными свойствами любви.
} 
где встречались продавцы воды, кочевые аборигены пустынь, бродячие богомольцы, нищие и богатые торговцы. Как правило, действие этих произведений проходит в безводных пустынях и в известных восточных городах: Тегеране, Ширване, Хачмасе, Шемахи, Тебризе, Багдаде, Дамаске. Аналогичные волшебные сказки весьма популярны в народном творчестве горцев: «Илясна гъизил балугъ» («Ильяс и золотая рыбка» - табас. яз.) [5, с. 260-268], «Гьуьлуьн руш» («Морская девушка» - лезг. яз.) [5, с. 208-218], «Пачагъад духарыклады махв» («Сказка о сыне падишаха» - рутул. яз.) [5, с. 291-298], «Рустам Зал» («Рустам Зал» - агул. яз.) [5, с. 76-86], «Бахтнан гъуш» («Птица счастья» - табас. яз.) [5, с. 355-366], «Паччагьдин аькюллу хва» («Умный сын падишаха»- лезг. яз.) [5, с. 534-545] и др.

Таким образом, вековые торговые, культурные, военные и бытовые контакты народов Южного Дагестана с народами Персии, существовавшие с V по XVIII вв., способствовали интенсивному влиянию богатой и древней персидской культуры на развитие устного народного творчества табасаранов, лезгин, агулов, рутулов, насыщая фольклор этих народов новыми эпическими сюжетами, отразившимися в волшебных, авантюрных, бытовых сказках и сказках о животных, восточными темами, нравственными идеями и яркими образами персонажей. А поэтическое творчество народов упомянутого региона (внеобрядовая лирика и свадебные песни), за редким исключением, навсегда обрело под влиянием персидской народной и ашугской поэзии каноническую форму «бенда», впитало различные традиции поэтики народной лирической песни.

\title{
СПИСОК ИСТОЧНИКОВ И ЛИТЕРАТУРЫ
}

1. Абдуллаева Э.А. Традиционная агульская народная поэзия (специфика, типология, поэтика). Автореферат кандидатской диссертации. Махачкала, 2006.

2. Вагабова Ф.И. Формирование лезгинской национальной литературы. Махачкала, 1970.

3. Ганиева А.М. Очерки устно-поэтического творчества лезгин. М.: Наука, 2004.

4. Крымский А.Е. История Персии, литературы и дервишской теософии. М.: Наука, 1986.

5. Свод памятников фольклора народов Дагестана: в 20 т. Т. 2. Волшебные сказки. М.: Наука, 2011.

6. Табасаран халкьдин мяълийир. Махачкала, 1990.

7. Ханмагомедов С.О. Дербент. Горная стена. Аулы Табасарана. М.: Искусство, 1979.

8. Шихиева М.Ш. Сказочный эпос дагестанских азербайджанцев: специфика, типология, поэтика: дис. ... канд. филол. наук. Махачкала, 2005.

Курбанов Магомед Муслимович, доктор филологических наук, профессор, ведущий научный сотрудник Дагестанский научно-исследовательский институт педагогики им. А.А. Тахо-Годи

367000, Россия, г. Махачкала, ул. Леваневского, 2

E-mail: kurbanov55@list.ru

\section{M.M. Kurbanov \\ HISTORICAL INFLUENCE OF THE CREATIVE TRADITIONS OF PERSIAN CULTURE ON THE DEVELOPMENT OF FOLKLORE IN SOUTHERN DAGESTAN}

\author{
DOI: 10.35634/2412-9534-2021-31-2-392-397
}

The article highlights the problems related to how ancient Persian culture in the Middle Ages had a powerful influence on the formation and development of folklore of the peoples of South Dagestan. Regional, ethnic, linguistic and cultural symbiosis was formed In the Derbent region, Tabasaran and Lezgistan in the V-XVIII centuries, which led the folklore of the Tabasarans, Lezgins, Azerbaijanis, resettled here Iranian-speaking Tats, Persians and Arabs to mutual enrichment and intensive development. Domestic, cultural and commercial relations led to the fact that most residents began to freely speak the "old Turkic", Persian, Lezgin and Tabasaran languages, which ethnic groups used in communication, trade and in everyday life. The result of the influence of Persian folk and Ashug poetry on the development of the creativity of the peoples of the region can be considered the formation of a single form of genre varieties of extra-ritual lyrics and wedding poetry in the folklore of Tabasarans, Lezghins, Agulians in the form of band-quatrains. Fairy tales of the peoples of the region were also positively influenced, they were enriched by Eastern plots, themes, ideas, colorful images, Persian toponymy and vibrant poetry of genres.

Keywords: Middle Ages, influence, contacts, South Dagestan, assimilation, bend-quatrain, borrowing, ethnic groups, genres. 


\section{REFERENCES}

1. Abdullaeva E.A. Tradicionnaya agul'skaya narodnaya poeziya (specifika, tipologiya, poetika). Avtoreferat kandidatskoy dissertacii [Traditional Agul folk poetry (specifics, typology, poetics. Abstract of the candidate's dissertation ]. Mahachkala, 2006. (In Russian).

2. Vagabova F.I. Formirovanie lezginskoj nacional'noj literatury [Formation of the Lezgian national literature]. Mahachkala, 1970. (In Russian).

3. Ganieva A.M. Ocherki ustno-poeticheskogo tvorchestva lezgin [Essays on the oral and poetic creativity of Lezgins]. M.: Nauka, 2004. (In Russian).

4. Krymskij A.E. Istoriya Persii, literatury i dervishskoj teosofii [History of Persia, literature and Dervish Theosophy]. M.: Nauka, 1986. (In Russian).

5. Svod pamyatnikov fol'klora narodov Dagestana: v 20 t. T.2. Volshebnye skazki [Set of monuments of folklore of the peoples of Dagestan: in 20 t. t. 2. Fairy tales]. M.: Nauka, 2011 (In Russian).

6. Tabasaran halk'din mya"lijir. [Tabasaran folk songs]. Mahachkala , 1990. (In Tabasaran).

7. Hanmagomedov S.O. Derbent. Gornaya stena. Auly Tabasarana [ Derbent. Mountain wall. Auls of Tabasaran]. M.: Iskusstvo, 1979. (In Russian).

8. Shihieva M.Sh. Skazochnyj epos dagestanskih azerbajdzhancev: specifika, tipologiya, poetika. Dissertaciya kandidata filologicheskih nauk [Fairy-tale epic of Dagestani Azerbaijanis: specifics, typology, poetics. Dissertation of the Candidate of Philological Sciences]. Mahachkala, 2005. (In Russian).

Kurbanov M.M., Doctor of Philology, Professor, Leading Researcher Dagestan Research Institute of Pedagogy named after A.A. Tahoe-Godi Levanevskogo st., 2, Makhachkala, Russia, 367000

E-mail: kurbanov55@list.ru 